\title{
3. Investigative journalism in a socially networked world
}

\section{AABSIRAACII}

This article explores how investigative journalists can join the network society by moving online, collaborating with other reporters and media outlets across regions and across national borders, yet publishing in newspapers which arguably remain the central stage of the public sphere (Carson, 2013). A better understanding of the potential of social media and web-based communications for undertaking journalistic investigations can lead to the adoption of a global perspective, enriching local, regional and national stories (Berglez, 2013). The research and collaboration for a transnational story published simultaneously in The Australian and The Times in London in 2013 may provide insights into the potential for the use of social media platforms and web-based communications for finding stories, collaborating and following stories into the social media to find leads to follow-up stories. This article questions whether the synergies between mainstream media and social media platforms may yield potentially high impact stories for major masthead newspapers and thus contribute to their sustainability. Connectivity with news sources has always been an important resource for journalists. Online networks may have the potential to expand the range of voices that can be heard and the issues that can be covered.

Keywords: collaboration, internet, investigative journalism, network theory, news sources, online networks, social media, web-based communication

\section{AMANDA GEARING}

Queensland University of Technology

$\mathrm{J}$ OURNALISM has become a node in the network society-a society in which almost everyone in the developed world has the power to publish words, images and video globally (Castells, 2010; van Dijk, 2012). Journalists and media companies have been slow to adopt internet-based journalism technologies that they perceived to be either unnecessary, because journalists already had wide networks of reliable contacts; or a threat, 


\section{INVESTIGATIVE JOURNALISM TRENDS}

because media companies did not want to believe the internet would steal the rivers of gold from classified advertising on which their profitability relied (Berglez, 2013; Nicholas, Williams, Martin, \& Cole, 1998; Spyridou, Matsiola, Veglis, Kalliris, \& Dimoulas, 2013), or too costly to embrace given falling revenues (Rosenthal, 2011). However some journalists and groups of journalists are embracing the potential offered by the emergence of the network society to enhance their investigative reporting skills. For example, groups of journalists have formed effective collaborations across national borders, such as the International Consortium of Investigative Journalists (ICIJ) and the Center for Investigative Reporting (CIR). The ICIJ and CIR are two of more than 40 non-profit centres funding investigative journalism projects in the United States via donations from philanthropic foundations and relatively small individual public donations (Birnbauer, 2010).

Both the ICIJ and the CIR have produced significant global multi-platform investigative journalism coverage (Bacon, 2011). The oldest international consortium of journalists, the ICIJ, began in 1997, and now has 160 reporters in 60 countries (ICIJ, 2013). Members choose which issues to investigate based on the global nature of the topics, for example the international water market and the international trade in carbon credits by the fossil fuel lobby (Bacon, 2011).

In a major step towards the introduction of collaborative reporting into the Australian media landscape, the first national investigative journalism conference in Australia was held in 2011. The conference was run jointly by the Australian Centre for Independent Journalism and the Australian Broadcasting Commission and heard mostly anecdotal presentations from investigative journalists about their work, including from Sue Spencer and Nick McKenzie on their reporting on the Securency banknote scandal; and Linton Besser and Dylan Welch who investigated the NSW Crime Commission, among others (Morton, 2012, p. 15). At the conference, US-based CIR director Robert Rosenthal-famous for his role in copying the Pentagon Papers and later as executive editor of the New York Times - described successful investigative journalism in the digital age as journalism which captures several audiences by publishing across several platforms. The various platforms represent each of the spokes in a wheel that contribute a sector of audience, increasing the overall audience of the coverage (Morton, 2012, p. 14). His take-home message to the conference delegates was to 'tell the story in a lucid way and push 
it out on every platform' including newspaper, radio, websites, social media, interactive multimedia and animation (Rosenthal, 2011).

Recognition of the increasing connectedness of causes and effects around the world has led to the formation of consortia of academics and student reporters, such as the Global Environmental Journalism Initiative (GEJI), formed by nine tertiary institutions in Europe and Australia (Bacon, 2011). Another academic-student collaboration, Project Censored, which started in Canada and the United States in the 1970s, to report under-covered or 'censored' stories, has grown into a network of 200 academics with more than 1000 students, from 30 tertiary journalism institutions (Bacon, 2011). Students with knowledge and skills who graduate and move into the profession will provide a source of skilled practitioners who could be expected to thrive in the journalistic node of the network society and to have an increasingly 'global' outlook. Bacon has urged journalism academics to practise global investigative journalism and to involve their students in 'collaborative investigation across time and space' via the GEJI (Bacon, 2011). Harnessing the skill and manpower of hundreds of academics and thousands of journalism students as an editorial resource, she argues, has the potential to produce global journalism in the public interest (Bacon, 2011, p. 45). Initial GEJI projects have included coverage of issues such as renewable energy, plastic bag usage and climate change. Bacon's recognition of the need for a global perspective on such topics echoes Steven Ward's call for a radical rethinking of journalism as a responsible global citizen when he said that, 'Journalists' primary allegiance is to truthful, independent informing of a global humanity' (Ward, 2005, p. 328).

Facing the reality of the rise of the network society and the media's changed role in it may hold the potential to empower investigative journalists and newspapers which still publish the majority of investigative journalism in Australia (Carson, 2013). If journalism is re-framed as a node in the network society, then network theory - the study of nodes in networks and the connections between them - may prove to be a useful analytical tool for examining journalism in the present, and thinking about the possibilities for the future. Although network theory developed in the field of mathematics it has been used in many disciplines to explain patterns of relationships between people, groups and artefacts such as documents (Hanneman \& Riddle, 2011). Sociologist John Scott showed how researchers in the arts could use network theory for their work in non-mathematical disciplines (Scott, 1991). Although 


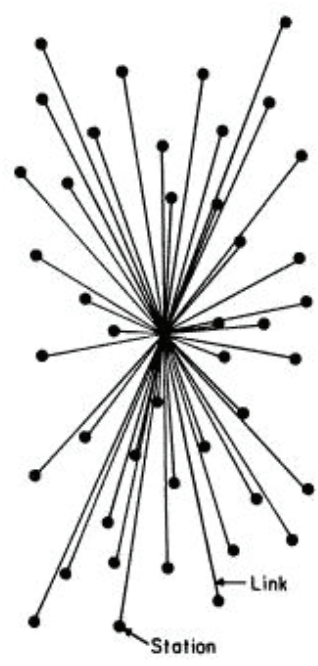

CENTRALIZED

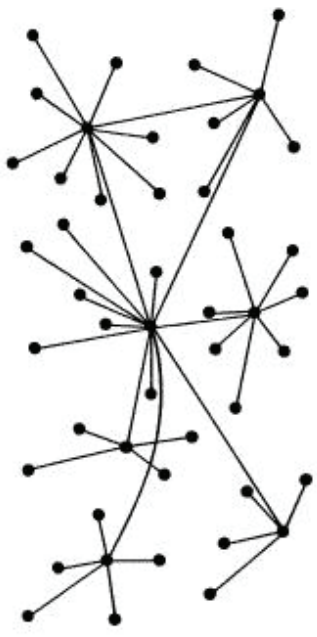

DECENTRALIZED

(B)

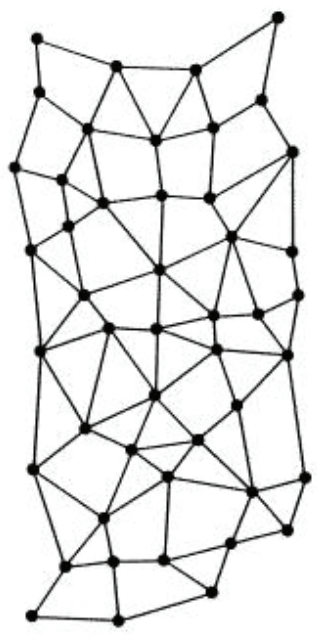

DISTRIBUTED

(C)

Centralised, decentralised and distributed networks from 'Beating the vulnerability problem' (Baran, 1964, cited in Boyer 2013).

he was writing before the emergence of networked social media, the concepts he describes are useful for studying the network connections made possible by the internet. Paul Baran described three basic types of networks as early as 1967: centralised networks, decentralised networks and distributed networks, as illustrated in Figure 1. Baran's purpose was to illustrate how decentralised communication infrastructure was more vulnerable during the Cold War, if it sustained enemy attack, compared with less centralised configurations (Baran, 1964).

De-centralised networks would prove more robust if they were damaged because remaining nodes could still connect with at least some other nodes rather than be isolated. Dominic Boyer referred in 2013 to Baran's three types of networks to illustrate how the centralised distribution of news by traditional media outlets is being partially replaced by audience members using social media platforms to spread news via more decentralised social networks (Boyer, 2013). Researchers have used social network analysis to better understand 
the dynamics of overall networks as well as the attributes of individual nodes and links in the networks. Network structures can be compared according to various factors including their density or whether there are cliques or smaller groups within the network (Scott \& Carrington, 2011). Nodes and links can be compared for various attributes such as their centrality, or isolation (Scott \& Carrington, 2011).

Networks are a key concept in the information age. Spanish sociologist Manuel Castells, who has been described as 'the first significant philosopher of cyberspace' (The Economist, 1999) for his three-volume series of books on the economics and social dynamics of the information age, concluded that 'dominant functions and processes in the Information Age are increasingly organised around networks'(Castells, 1996). His theories were developed during an academic career in which he worked at 21 different universities in Europe, the Americas and Asia. After decades of research in three continents, Castells argued that 'the flexibility and adaptability of networks' makes them much more effective than vertically-structured lines of communication or centralised bureaucracies (Castells, 1996). In observing the communication field, Castells noted that 'the production and distribution of words, sounds and images .... are shaping life and being shaped by life at the same time' (Castells, 1996, p. 2).

Media and communications professor Peter Berglez adopted Castells' theories and applied them to the field of journalism and, in the process, redefined the concept of 'global' (Berglez, 2013). Instead of global journalism being seen as a public discourse between nations, Berglez argued that global journalism is a theory and practice of journalism which is global in outlook rather than being either local, national or international in outlook (Berglez, 2013). In practice, global journalism adopts digital technology and uses it creatively to develop advanced ways of covering 'an ever more complex global reality' (Berglez, 2013). Combining the ideas of Castells' network theory with the work of Berglez, we can explore the new potential of journalism to link via social media with individuals and networks across the world. We can also explore how web-based communication can enable reporters to investigate and report transnational stories.

Investigative journalists who bring their analogue reporting skills into the digital space may be able to find, or be found by, global stories, possibly by using social media platforms, by collaborating with other reporters or 
arranging media outlet collaborations either domestically or internationally. This interaction in the online space may yield synergies between the social media and the legacy media that will enhance the role of investigative journalism in calling power to account.

While newspapers have embraced the social media to an extent by encouraging reader feedback to stories via their news websites, Facebook pages, Twitter and email, there is a scarcity of research into how the social media and web-based communication tools can be used to find investigative stories and to place them into the public sphere. Research in this field could produce a model for using emerging technologies in investigative reporting, especially for global investigative journalism about sensitive or controversial material.

Failing to conceptualise journalism as part of the network society can lead to an unnecessary narrowing of focus for possible story leads. The battered analogue indexed contact books so many reporters still rely upon linking them with relatively small networks compared with the available networks contactable online. Journalists who have websites, social platform pages and blogs, for example, have access not only to their personal contacts but are also contactable by contacts of contacts, interest groups and other potential news sources. There are also new internet-based communications technologies that are free, flexible and adaptable, such as Dropbox which allows easy transfer of large files and folder sharing; and Skype, where people can be interviewed face to face or voice to voice, with added functions such as text chat and document transfer.

Collaboration between reporters and between media outlets is also beginning to emerge as an important tool for investigative journalism in the network society. This is a recent but significant change from journalists withholding contacts and story leads from colleagues even within the same newsroom. The possible benefits of collaboration between reporters in different states or countries may enable more complex stories to be researched and published for far less cost than was previously possible when international travel was necessary. Collaboration between media outlets is also beginning to emerge as a way for different media, for example newspapers and television, to share the cost and effort of investigations, to maximise their audience and enhance the political impact of the story. Stories which are then shared by engaged traditional media audiences sharing them with their social media networks can then yield breaking news stories that are then covered in the mainstream 


\section{Figure2: Synergies emerge as news coverage moves}

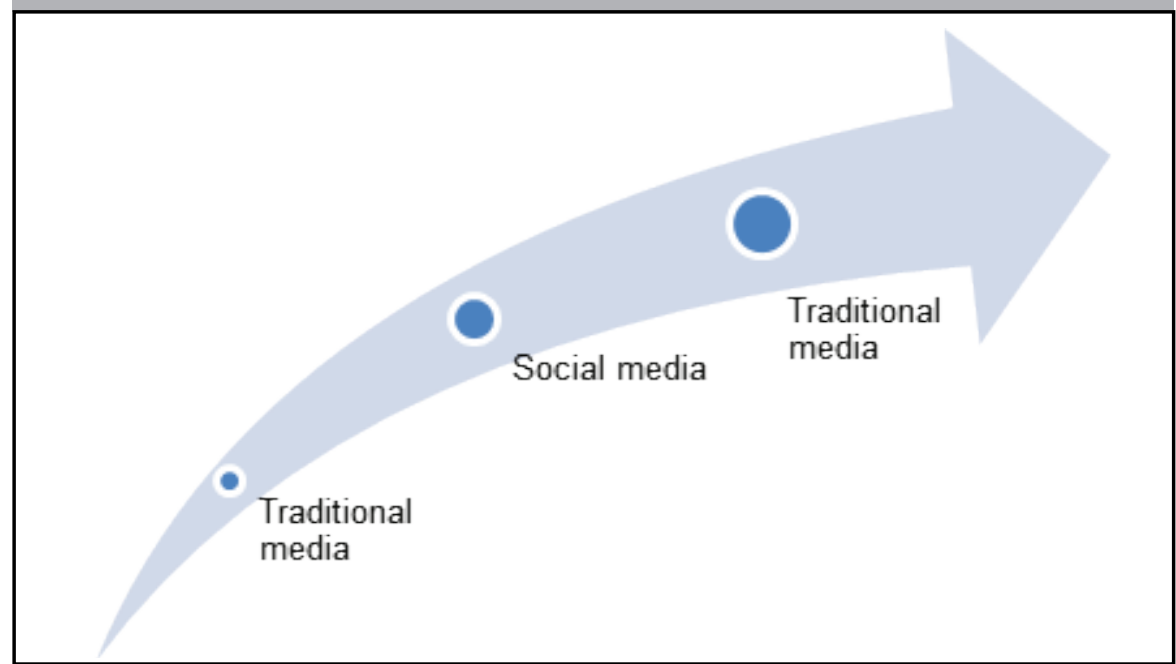

Synergies emerge as news coverage moves from traditional media to the social media and back.

media. Social media searches now make it possible for reporters to follow their own breaking news onto social media platforms to look for reaction and follow-ups, for example, by using keyword internet searches for comments, blogs, tweets and related websites and Facebook pages.

All the concepts outlined above were exemplified in a transnational investigation that was initiated by a news source in Britain who contacted a reporter in Australia seeking coverage of his story. That initial contact led to a six month investigation and resulted in the first ever collaboration between journalists at The Times in London and The Australian and collaboration between the newspapers to publish an exclusive story simultaneously.

\section{A UK-Australian story}

The genesis of the investigation was an email from a reader in the United Kingdom to myself, a reporter in Australia, in late 2012. The reader, Eli Ward, had seen television news coverage of the Jimmy Savile pedophilia case in Britain that stirred memories of his own sexual abuse by a senior cleric in Britain, Robert Waddington, who had been a former Dean of Manchester. Church communication patterns between the institution and individuals are 
typically centralised with only approved information passing to individuals. Victims of abuse have been typically isolated from other victims. However, the rise of social media networks which are more decentralised now enable once-isolated individuals to locate and communicate with people who they have been prevented from finding in the past. Ward initially approached local and national newspapers in England seeking to expose Waddington's criminality, but both approaches were rejected. He also made a crime report to Greater Manchester Police that resulted in a police investigation. Information from the mainstream media about the Jimmy Savile case gave Ward insights into his own victimisation that then drove him to seek more information and validation of his experience. Ward searched the world wide web for information related to the locations where Waddington had worked, using simple keyword Google searches. His searches revealed an online article published in 2009 (Gearing, 2009) mentioning another cleric jailed for sex offences at the school in Queensland, St Barnabas' School in Ravenshoe, where Waddington had been the previous headmaster. The searchability of digitised archived newspapers around the world made it possible for Ward to validate the facts he knew and to add new information. The information he gathered from his internet searches provided enough evidence to persuade him to make contact via email with the reporter in Australia who had written the article. For the first time Ward stepped from his previous position of anonymity and isolation and made contact via easily accessible Web communications technologies. His email briefly outlined his status as a victim of clergy sexual abuse and sought my interest in his story. The portability of email connections meant that I was able to reply to his email even though I was overseas, and arranged to meet him for an interview in the UK. Ward's ability to connect with a reporter with previous publications relevant to his life, highlights the importance of journalists being part of the network society and being findable via email, website or social media platforms such as Facebook, Twitter or YouTube, in order to receive these types of leads.

I responded to Ward's email and exchanged emails over the following few days. We met a few weeks later for an initial interview in England. Ward was in fragile health but was accessing professional medical care. The only other victim of Waddington that Ward knew about had died as a result of a suspected suicide some years earlier. Nevertheless, Ward had launched a civil action.

Since Ward had no other victim names who could verify his allegations, 
I used the background information from the initial interview to conduct Web searches to gather and verify the facts. I used different keyword Google searches and scrolled through many pages of results produced by those searches. Information already gathered was verified and expanded and a potential news contact emerged in Australia. Reliable biographical information was obtained from four published obituaries in two regional and two national newspapers honouring the late Dean of Manchester who had died in 2007 (Guide, 2007a, 2007b; The Telegraph, 2007; The Times, 2007). All of the obituaries described Waddington in glowing terms as a dedicated priest who had worked on the 'mission field' in Australia in the 1950s and 1960s and who returned to England, rising to senior positions in the church, until his retirement as Dean of Manchester Cathedral in 1994. In addition to verifying career details, they raised suspicion that Waddington had been detected offending in the 1950s and had been sent to Australia. The young priest with a blue ribbon education from Cambridge University was initially posted to a London parish but after only a short time he was sent to Australia to a school in regional Queensland as chaplain - certainly not a promotion.

Suspicions were also raised by Waddington's career path because each role centred on children and had provided him with trusted access to children-first as a school chaplain and then headmaster-despite his having no educational qualifications. Once back in England, Waddington was appointed general secretary of the General Synod Board of Education in Britain and then, by Royal appointment, became the Dean of Manchester. In this role he personally cared for the boys in the two Cathedral choirs. One of the obituaries ventured that he 'had a special gift for teaching boys, which proved useful in his later cathedral appointments when he had responsibility for choristers' and that he was a member of the Oratory of the Good Shepherd, a celibate order of Anglican priests for over three decades, eventually rising to become its Superior (The Times, 2007).

While I was still in the UK, investigations by Greater Manchester Police revealed an internal church report, a Child Protection Report, that documented two complaints by Ward's two sisters and that there had been 'an Australian complaint' about Waddington, although the name of the complainant was not given (Diocese of Manchester Child Protection Officer, 2003). If Waddington were a serial sex offender, as alleged, there would be other victims, in Australia, in Britain, or perhaps both. Tracking them down without having any names was a 
major obstacle. Yet, if no others could be found, Ward's allegations would be difficult to establish. I returned to the internet and made several keyword Google searches. This time I located a post to a social website from a named former student, Bim Atkinson who had attended the Ravenshoe school in far North Queensland where Waddington had been headmaster (Atkinson, n.d.). It read in part: 'My pedophile headmaster and abusive caner was The Most UnReverend Robert Waddington. Some of my other teachers were Brother Peter Gilbert (a Waddington-induced pedophile who is now in jail). ... The criminal history of Gilbert was later verified from court records provided by the South Australian Court.

On my return to Australia, a search of the White Pages Online revealed Atkinson's phone number in Ravenshoe. He was willing to be interviewed. Atkinson had filed a civil action against the Diocese of North Queensland in 1999 and requested that his knowledge of Waddington's criminality be forwarded to the Diocese of York, where Waddington was living in retirement, to ensure children could be protected from him. Atkinson had been the source of 'the Australian complaint' mentioned in the Child Protection Report. Although Ward and Atkinson were victims of the same offender they had been isolated from each other by the church's centralised communication network. Overcoming this imposed isolation proved to be a comfort (that they were not lone victims) but also increased their anger towards both Waddington and the church institution, and gave them increased determination to seek justice for Waddington's offences. Atkinson had hundreds of documents including police statements, legal documents and artefacts of his schooling such as class photographs and school publications.

Over subsequent weeks, early morning and late evening Skype interviews were conducted with Ward in the UK. At the time the two men did not contact each other directly as I was concerned about possible adverse affects to their health, given the sensitive nature of their experiences. Contact was maintained with both men via email, Facebook and Dropbox with them initiating almost all of this contact. I was cautious about the potential risks to both men of the glare of publicity and therefore gave them several weeks to ponder whether they wanted to engage in media coverage that could potentially expose them to negative feedback from family, friends or readers. Over time, both men became more determined to engage with the media. Ward and Atkinson were therefore introduced to each other via a Skype conference call a few weeks after my 
initial contact with Atkinson. Ward and Atkinson now were part of a network consisting of a journalist, police officers, another victim and a lawyer-and instead of being isolated they could now communicate freely via the Internet. One or both men may at this stage have found sufficient resolution that they no longer wanted to go public with their story. Both men became more determined about the potential of their joint media engagement to expose Waddington's crimes and the church's cover-up of his criminality over decades. I wrote an extended feature article, verifying the facts from available documents including the newspaper obituaries, police statements, emails, letters, photographs and court documents (McKenna \& Gearing, 2013a).

Unlike established collaborations of journalists as mentioned earlier in this article, where groups of reporters are formed before an investigation is undertaken, the collaborations on this story were arranged once the main facts of the story were verified. The controversial nature of the story and its potential impact meant I needed to try to secure the interest of national newspapers with a strong track record of public service journalism both in Australia and in England. The issue of the handling of child sexual abuse by institutions in Britain was already on the public agenda and in Australia, the issue had precipitated the Royal Commission into Institutional Responses to Child Sexual Abuse. Using my existing contacts, I approached a senior reporter at The Australian, Michael McKenna, who was willing to collaborate with me on the story and also with a reporter, hopefully from the London-based News Limited paper The Times. The crimes editor, Sean O'Neill, was willing to collaborate and to arrange, with McKenna, the co-publication of the story in The Australian and The Times.

Once the story was published, the associated online articles were republished around the globe and were shared via social media platforms including websites and blogs. I used keyword Google searches using words from the published story to see if other victims of Waddington might emerge in the social media, given the long period of Waddington's offending, established from the Atkinson and Ward cases, stretching from the 1960s to the 1990s. These searches revealed an anonymous post made by another victim of Waddington to a blog in Britain. This victim wrote that an archbishop quoted in The Times who claimed Waddington was too old and sick to be investigated, was wrong, saying that on the contrary, Waddington had travelled at the time to France, accompanied him to the ballet and had been driving around in a 
convertible. I emailed the blog master who forwarded my request to make contact with the author of the anonymous blog post. An interview with him produced a follow-up story that exposed church staffers who had lied to the Australian victim, Atkinson, during his civil action (O'Neill, 2013). The three reporters in Britain and Australia, working collaboratively, were able to pass information and story leads back and forth by email, and new leads could be chased up 24 hours a day in one or other country. This resulted in very fastpaced breaking news coverage.

The two newspapers also collaborated on the publication of a joint exclusive transnational story. Front page space and feature space was held by both papers for the initial story and a follow-up story on consecutive days, as agreed pre-publication. The time difference between Australia and Britain was managed by an agreement in which The Australian published the initial stories only in hardcopy, while The Times published at the same time online, enabling the papers to publish simultaneously, despite the 10 hour time zone difference. The arrangement is an example of how news is becoming more global and that digital technologies can be used to report what Berglez describes as 'an ever more complex global reality'.

Traditional reader feedback was received to the hard-copy newspaper articles and produced another significant follow-up story. Another victim of Waddington, Ray Munn, from England, was living in Adelaide when he saw Waddington's face in a photograph on the front page of The Australian and contacted the Australian reporting team via the newspaper. Munn's information extended the length of the cover-up of Waddington's crimes by the church in England to more than 50 years (McKenna \& Gearing, 2013b). Munn confirmed Waddington had been caught offending against him and some other choir boys in London and that Waddington had been summarily despatched by ship to Australia more than 50 years earlier.

The political impact of the stories was significant. The sexual abuse of children within institutional settings was already a controversial issue that was high on the public agenda in both countries. Two independent church inquiries were ordered in Britain and are ongoing at the time of going to press. The allegations in Australia were referred to the Royal Commission into Institutional Responses to Child Sexual Abuse.

\section{Conclusion}

This investigation exhibits several important aspects of the transition of inves- 
tigative journalism into a functioning node in the network society. Hallmarks of the network society are the rise of decentralised networks that enable universal participation, connections via social media and fast and wide-ranging information gathering. In this case study, the original news source, Eli Ward, was able to locate a relevant article written by a reporter across the globe using simple keyword Google searches, and was able to make contact with the reporter. Another victim of the same offender was located in Australia, despite the searcher having no victim name as the basis for a search-a task that would have been very time-consuming, prohibitively costly or impossible before the emergence of the network society. Both Ward and Atkinson were willing to waive their anonymity and to speak publicly of their experiences and to be photographed and videoed, despite each having endured many years of hardship, isolation and institutional denials. Both men were gratified that their engagement with the mainstream media led to other victims also being located and enabling their evidence to be publicly corroborated.

Reporter collaborations in Australia and the UK resulted in a virtually continuous investigation for several weeks as the reporters in Australia and Britain shared their copy and photographs by email and thus created an effective 24-hour investigative team. The newspaper collaborations resulted in simultaneous coverage of an exclusive story-a first for both publications. The story was picked up by radio and television news in Britain and Australia. The issue of the victimisation of children by sexually abusive clerics became a topic of serious public and political debate. Findings of the Manchester Diocese Inquiry, due in October 2013, were delayed until at least April 2014.

Given this example of transnational investigative reporting, it seems possible that online networks could offer new ways of working for investigative newspaper journalists in the network society, to expand both the range and depth of stories that they cover. The potential uses of social media platforms and web-based communications are more than the sum of the parts because the network connections they enable can provide synergies that facilitate the coverage of global stories, including stories involving sensitive or controversial topics. Investigative newspaper journalists who link with online networks have the potential to expand the range of voices that can be heard and the types of stories that can be told as they call the powerful to account and give voice to the voiceless. 


\section{INVESTIGATIVE JOURNALISM TRENDS}

\section{References}

Atkinson, B. (n.d.). Memories from St Barnabas Boarding School, Ravenshoe Nth Qld [Blog post]. Retrieved from www.oldfriends.co.nz.

Bacon, W. (2011). Investigative journalism in the academy-possibilities for storytelling across time and space. Pacific Journalism Review, 17(1), 45-66.

Baran, P. (1964). On Distributed Communications Networks. IEEE Transactions on Communications Systems, 12(1), 1-9.

Berglez, P. (2013). Global journalism: Theory and practice. New York: Peter Lang.

Birnbauer, B. (2010, 13 September). When revenue plays no part in revealing the truth, The Australian.

Boyer, D. (2013). The life informatic: Newsmaking in the digital era. London: Cormnell University Press.

Carson, A. (2013). Investigative journalism, the public sphere and democracy: The watchdog role of Australian broadsheets in the digital age'. (Unpublished Doctoral Thesis), University of Melbourne, Melbourne.

Castells, M. (1996). The rise of the network society. Cambridge, MA: Blackwell.

Castells, M. (2010). End of millennium the information age: Economy, society, and culture (2nd ed., Vol. III). Oxford: Wiley-Blackwell.

Diocese of Manchester Child Protection Officer. (2003). Diocese of Manchester Child Protection Report. Unpublished: Anglican Diocese of Manchester.

Gearing, A. (2009, 29 April 2009). Archbishop's Chaplain behind bars at last, Online Opinion. Retrieved from www.onlineopinion.com.au.

Guide, D. (2007, 13 April). Robert Waddington, News \& Star. Retrieved from www. newsandstar.co.uk.

Hanneman, R. A., \& Riddle, M. (2011). A brief introduction to analysing social network data In J. Scott \& P. J. Carrington (Eds.), The Sage handbook of social network analysis. London: Sage.

ICIJ. (2013). The International Consortium of Investigative Journalists. from www. icij.org.

McKenna, M., \& Gearing, A. (2013a, 10 May 2013). Church's wall of silence on sexual abuse, The Australian. Retrieved from www.theaustralian.com.au.

McKenna, M., \& Gearing, A. (2013b, June 1.). Robert Waddington's cycle of abuse stretches beyond 50 years, The Australian. Retrieved from www.theaustralian. com.au.

Morton, T. (2012). This wheel's on fire: New models for investigative journalism. Pacific Journalism Review, 18(1), 13-16.

Nicholas, D., Williams, P., Martin, H., \& Cole, P. (1998). The media and the internet: Final report of the British library funded research project 'The changing information environment'. London: The Association for Information Management.

O'Neill, S. (2013, May 16). Dean was still preying on choirboys when Church ruled him too ill to be a risk, The Times. Retrieved from www.thetimes.co.uk.

Rosenthal, R. (2011, 16 September). New investigative reporting models: Opportunities and challenges. Paper presented at the Back to the Source conference, Sydney. 
Scott, J. (1991). Social network analysis: a handbook. London: Sage.

Scott, J. G., \& Carrington, P. J. (Eds.). (2011). The Sage handbook of social network analysis. Portland, USA: Sage.

Spyridou, L.-P., Matsiola, M., Veglis, A., Kalliris, G., \& Dimoulas, C. (2013). Journalism in a state of flux: Journalists as agents of technology innovation and emerging news practices. International Communication Gazette, 75(1), 76-98.

The Economist. (1999). The rise of America's high-tech industry is not just a windfall for presidential hopefuls. It could also be a godsend for the liberal political tradition. 28 October 1999. Texas, USA: Liberty.com www.economist.com/node/253625

The Telegraph. (2007). The Very Reverend Robert Waddington. from Telegraph Media Group Limited www.telegraph.co.uk.

The Times. (2007, 23 March 2007). The Very Reverend Robert Waddington, The Times. van Dijk, J. (2012). The network society (3rd ed.). London: Sage.

Ward, S. J. A. (2005). The invention of journalism ethics: The path to objectivity and beyond. Montreal, Ithaca: McGill-Queen's University Press.

Amanda Gearing is a journalist, author and broadcaster based in Queensland. She completed a Master of Arts (Research) in 2012. Her creative work, The day that changed Grantham, won a Walkley Award for Best Radio Documentary in 2012. Her book The Torrent: Toowoomba and the Lockyer Valley about the January 2011 flood was published by UQP in 2012. Gearing is currently enrolled in a PhD at Queensland University of Technology. gearingap@bigpond.com 